\title{
Penilaian Kawasan Hutan dalam Penentuan Kelayakan Luas Areal Perkebunan Kelapa Sawit (Suatu Pendekatan Konseptual)
}

\author{
Akhmad Yani* \\ Universitas Tanjungpura
}

\begin{abstract}
Most studies valuation that have been described previously including forest ecosystems do not see the forest ecosystem services as natual capital / natural assets and even the socioecological context. The implication is that forest ecosystem services are considered as an economic asset / economic capital. the concept of value used in the valuation is the concept of the value of output. Though the forest ecosystem services has the characteristics of a sustainable dynamic and as part of the life supporting system including the ability resilience and self-terrific capacity. So that the forest ecosystem is no longer seen as economic assets, but with the characteristics of the dynamic and sustainable forest ecosystem is seen as natural or natural capital assets. The current perspective marginalize other forest ecosystem functions, such as socio-economic functions. Whereas the concept of an insurance value of forest ecosystems is not just the case as seen from the perspective as natural capital, but the role of social values in maintaining the sustainability of forest ecosystems is crucial, as reflected by the presence of heritage value, and existence value. So that the insurance value of the forest ecosystem occurs because the forest ecosystem serves as a natural asset / natural and social capital assets / social capital.
\end{abstract}

Keywords : Prinsip Nilai Asuransi, Penilaian Ekosistem Hutan, Social Economy and Environment Compromise Index (SEEC), Indeks Ky.

\section{PENDAHULUAN}

Tidak dapat dipungkiri bahwa investasi perkebunan kelapa sawit menghasilkan profit yang sangat prospektif bagi para investor. Selama ini salah satu instrumen dalam menentukan kelayakan konversi kawasan hutan menjadi lahan perkebunan kelapa sawit adalah instrumen Cost-Benefit Analysis. Instrument valuasi ini pada dasarnya lebih menitikberatkan pada aspek manfaat ekonomi dalam perspektif jangka pendek tanpa memperhitungkan dampak eksternalitas kerusakan lingkungan akibat konversi hutan menjadi lahan perkebunan kelapa sawit, sebagai bagian dari komponen biaya. Instrumen valuasi dengan menggunakan cost-benefit analysis yang menitikberatkan aspek finansial

\footnotetext{
* Korespndensi: Akhmad Yani, Jurusan Ilmu Ekonomi, Fakultas Ekonomi, Universitas Tanjungpura, Jalan Prof. Dr. H. Hadari Nawawi, Pontianak, Indonesia. Email : yand_ds@yahoo.com.
} 
atau ekonomi ini menjadi salah satu pendorong terjadinya konversi ekosistem hutan menjadi lahan perkebunan kelapa sawit.

Untuk mempertahankan manfaat ekosistem hutan dengan berbagai fungsinya, diperlukan suatu valuasi yang bersifat komprehensif dan terintegratif serta sustainable. Disamping itu, valuasi terhadap manfaat dari fungsi ekosistem hutan harus menganut prinsip nilai asuransi (insurance value). Prinsip nilai asuransi ini adalah suatu prinsip nilai yang melihat bahwa nilai manfaat dari fungsi ekosistem hutan, bukan hanya nilai manfaat yang dapat diperoleh pada saat sekarang, tetapi nilai manfaat yang dapat diberikan oleh fungsi ekosistem hutan secara berkelanjutan di masa yang akan datang.

\section{TINJAUAN PUSTAKA}

\subsection{Penilaian Total Ekonomi Sumberdaya Hutan}

Secara konseptual nilai total ekonomi sumberdaya hutan terdiri dari: (1) nilai penggunaan (use value) dan (2) nilai bukan penggunaan (non use value). Selanjutnya nilai penggunaan terdiri dari nilai penggunaan langsung (direct use value -DUV) dan nilai penggunaan tidak langsung (indirect use value- IUD) serta nilai pilihan (option value-OV). Sedangkan nilai non penggunaan yaitu nilai warisan (bequest value -BV) dan nilai eksistensi (existence value-EV). Berdasarkan konsep nilai ekonomi yang dikemukakan di atas, secara matematis, Manusinghe (1992) membuat formula sebagai berikut:

$\mathrm{TEV}=\mathrm{UV}+\mathrm{NUV}$

Atau,

$\mathrm{TEV}=(\mathrm{DUV}+\mathrm{IUV})+(\mathrm{BV}+\mathrm{EV})$

Nilai penggunaan langsung dari suatu sumberdaya hutan dinilai atas dasar kontribusi produksi dan konsumsi dari sumberdaya hutan tersebut. Sementara itu nilai penggunaan tidak langsung mencakup manfaat yang diperoleh dari keberadaan sumberdaya hutan dan lingkungan untuk mendukung produksi dan konsumsi saat ini. Nilai pilihan didasarkan pada kesediaan konsumen untuk membayar (willingness to pay) untuk sumberdaya hutan yang belum digunakan atau kesediaan membayar untuk menghindari resiko tidak tesedia di masa mendatang. Nilai warisan adalah nilai dari pengetahuan mengenai ketersediaan manfaat historis dari suatu sumberdaya hutan dan dapat diteruskan kepada generasi yangakandatang. Nilai eksistensi didasarkan pada kepuasan karena mengetahui sumberdaya tersebut tetap tersedia, meskipun penilainya tidak menggunakannya secara intensif (Manusinghe, 1992). Namun secara lebih komprehensif Munasinghe (1992) membagi nilai total ekonomi(TEV) terhadap sumberdaya hutan ke dalam nilai penggunaan dan nilai non penggunaan. Nilai penggunaan dibagi ke dalam nilai langsung, nilai tidak langsung dan nilai pilihan. Sedangkan nilai non penggunaandibagi kedalam nilai eksistensi dan nilai 
warisan.Pembagian nilai total ekonomi (TEV) sumberdaya hutan oleh Munasinghe (1992) dituangkan secara diagram sebagai berikut:

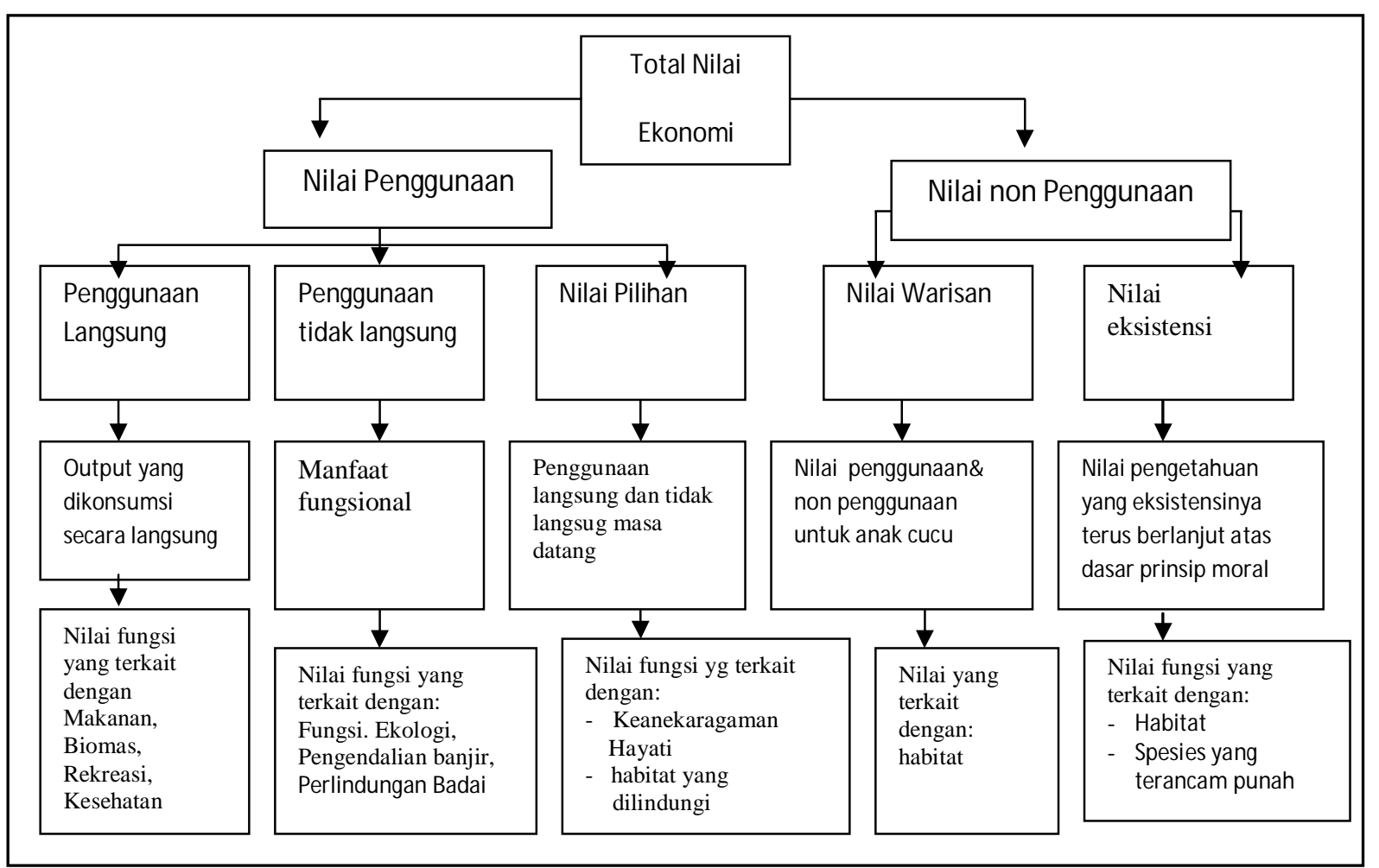

Sumber : Munasinghe (1992)

\section{Gambar 1. Klasifikasi Nilai Sumberdaya Alam}

\subsection{Internalisasi Dampak Lingkungan dan Sosial Ekonomi Perkebunan Kelapa Sawit}

Konversi hutan alam untuk perkebunan kelapa sawit terus berlangsung sampai saat ini dan telah menjadi salah satu sumber perusakan hutan alam bahkan menjadi ancaman terhadap hilangnya kekayaan keanekaragaman hayati ekosistem hutan hujan tropis. Dampak negatif terhadap lingkungan menjadi bertambah serius karena dalam praktiknya pembangunan industri dan terutama pembangunan perkebunan kelapa sawit tidak hanya terjadi pada kawasan hutan konversi, melainkan juga merambah ke kawasan hutan produksi, bahkan di kawasan konservasi yang memiliki ekosistem yang unik dan mempunyai nilai keanekaragaman hayati yang tinggi (Manurung, 2000; Potter and Lee, 1998a). Selanjutnya, praktik konversi hutan alam untuk pembangunan perkebunan kelapa sawit seringkali menjadi penyebab utama bencana kebakaran hutan dan lahan, terutama kondisi ini terjadi di Indonesia. Oleh karena itu, pembangunan perkebunan kelapa sawit turut bertanggung jawab sebagai salah satu penyebab utama bencana kebakaran hutan dan lahan seluas 10 juta hektar pada tahun 1997/98. Total kerugian 
ekonomi akibat kebakaran hutan dan lahan pada tahun 1997/98 diperkirakan mencapai US\$ 9,3 milyar (Bappenas, 1999).

Akibat konversi hutan alam menjadi areal pembangunan perkebunan kelapa sawit telah menimbulkan berbagai dampak negatif terhadap lingkungan. Pengubahan ekosistem hutan hujan tropis diubah menjadi areal tanaman monokultur, muncul serangan hama dan penyakit, perubahan aliran air permukaan tanah, meningkatnya erosi tanah, dan pencemaran lingkungan akibat pemakaian pupuk dan pestisida dalam jumlah yang banyak, serta berbagai dampak negatif lainnya terhadap eco-function yang dapat dihasilkan oleh ekosistem hutan alam tropis - menimbulkan biaya yang ditanggung oleh pihak yang tidak terkait dengan kegiatan perkebunan kelapa sawit, sehingga selayaknya diperhitungkan sebagai biaya lingkungan.

Permasalahan lainnya, pembangunan areal perkebunan kelapa sawit dalam skala besar tidak jarang menyebabkan dipindahkannya masyarakat lokal yang tinggal di dalam wilayah pengembangan kedua sektor tersebut. Ganti rugi tanah pada areal pengembangan seringkali menimbulkan permasalahan karena tidak dibayar dengan harga sesuai dengan apa yang sudah disepakati. Di samping itu, sering terjadi penyerobotan (pencaplokan) lahan masyarakat adat oleh perusahaan perkebunan kelapa sawit. Sebagai akibatnya, seringkali timbul permasalahan tuntutan lahan oleh masyarakat setempat terhadap areal perkebunan kelapa sawit yang sedang/telah dibangun. Berbagai permasalahan ini telah menyulut permasalahan konflik sosial yang berkepanjangan dan sangat merugikan semua pihak - terutama bagi masyarakat yang mengalami dampak negatif akibat pembangunan perkebunan kelapa sawit - sehingga biaya sosial yang harus dikeluarkan menjadi sangat tinggi. Namun demikian, perusahaan tidak pernah memasukan biaya lingkungan dan biaya sosial ini dalam analisis finansial pembangunan perkebunan kelapa sawit. Dengan melakukan internalisasi biaya sosial dan biaya lingkungan sebagai bagian dari aspek penilaian kelayakan kegiatan perkebunan kelapa sawit, diduga kuat bahwa nilai jasa lingkungan dari hutan lebih besar jika dibandingkan nilai perkebunan kelapa sawit.

\subsection{Valuasi Ekonomi Hutan Dengan Konsep Nilai Asuransi Dalam Perspektif Natural Aset}

Beberapa penelitian yang menggunakan extended cost-benefit analysis untuk mencari net present value dari jasa ekosistem hutan telah dilakukan oleh beberapa peneliti diantaranya sebagaimana yang dikemukakan berikut ini.

Alcorn (1989) melakukan studi dengan menggunakan metode Cost Benefit Analysis (CBA) untuk melakukan valuasi terhadap pilihan penggunaan hutan belukar di Mexico.Tujuan dari studi ini mencoba untuk mencari return yang paling tinggi dari kombinasi pilihan penggunaan hutan belukar. Fokus studi ini adalah menghitung manfaat bersih berkenaan dengan sistem sosial pengelolaan hutan yang dilakukan oleh petani 
lokal di Timur Laut Mexico pada tahun 1987. Sistem yang diterapkan adalah perpaduan perkebunan komersil (tebu dan kopi) dan perkebunan subsistencedalam pengelolaan hutan belukar. Temuan studi ini menyimpulkan bahwa apabila kopi ditanam disepanjang hutan belukar, maka total return on investment yang diperoleh kira-kira US \$598 per hektar, yaitu $65 \%$ dari total hasil keseluruhan. Dengan kata lain, pemanfaatan hutan belukar akan memberikan return yang tinggi jika ditanami dengan perkebunan kopi, tebu dan tanaman lokal. Namun penerapan metode CBA dalam studi ini tidak memperhitungkan biaya lingkungan maupun opportunity cost dampak konversi sebagian hutan belukar untuk dijadikan perkebunan kopi. Sehingga dengan metode perhitungan seperti ini, tentu saja nilai bersih yang dihasilkan oleh perkebunan kopi adalah yang paling tinggi.

Penerapan metode CBA juga dilakukan dalam melakukan valuasi terhadap total nilai ekosistem hutan. sebagaimana Lal (1990) melakukan estimasi total nilai ekonomi cadangan hutan India, termasuk nilai penggunaan langsung dan tidak langsung serta nilai bukan penggunaan. Nilai penggunaan langsung yang diamati adalah produk kayu dan non kayu, untuk pengembalaan ternak dan rekreasi. Sementara nilai penggunaan tidak langsung meliputi produksi oksigen, konservasi dan mempertahankan kesuburan tanah, siklus air dan pengaturan kelembaban udara, pengendalian polusi udara, perlindungan fauna dan flora. Sedang nilai pilihan dan non pilihan adalah konservasi keanekaragaman hayati. Hasil studi ini menemukan bahwa total nilai cadangan hutan India adalah 785.5 milyar Rupees per tahun. Dengan asumsi discount rate $5 \%$, maka diperoleh nilai NPV hutan India diperkirakan sebesar 15,910 milyar Rupee. Apa yang terlihat dari penerapan metode CBA dalam studi ini menunjukkan bahwa konsep ekosistem hutan lebih dilihat sebagai economic asset dengan menghitung nilai output, bukan melihat ekosistem hutan sebagai natural asset dengan konsep nilai asuransi.

Ruitenbeek (1992) melakukan studi dengan menerapkan metode CBA untuk menilai manfaat sosial dan ekonomi dari perlindungan 300.000 hektar mangrove di teluk Bintuni, Irian Jaya. Analisis ini mempertimbangkan 6 pilihan penggunaan untuk mangrove mulai dari memotong habis hingga melarang total penebangan hutan mangrove. Pilihan terbaik tergantung pada asumsi yang dibuat terkait dengan dampak penebangan mangrove terhadap produksi udang dan ikan di lepas pantai. Apabila dampaknya linier dan segera, maka pilihan pelarangan penebangan mangrove merupakan pilihan terbaik. Apabila hubungannya linier, tetapi baru menimbulkan dampak setelah 5 tahun, maka penebangan hutan dapat dilakukan secara selektif maksimal 25 persen. Sedangkan jika tidak ada keterkaitan, penebangan hutan mangrove memberikan NPV paling tinggi. Namun mengingat fungsi-fungsi ekologi hutan mangrove sangat penting, maka studi ini merekomendasikan untuk menetapkan pilihan pelarangan penebangan hutan mangrove, dengan menganggap bahwa dampak penebangan tersebut bersifat linier dan segera. Memperhatikan hasil studi ini dengan menggunakan metode CBA, terlihat bahwa penerapan metode CBA yang dipakai untuk membandingkan nilai beberapa alternatif pilihan terhadap pemanfaatan hutan mangrove, masih menggunakan konsep 
ekosistem hutan dilihat sebagai economic asset bukan sebagai natural asset. Sehingga konsep nilai yang dihasilkan adalah konsep nilai output bukan nilai asuransi dari jasa ekosistem hutan.

Sementara itu Beukering dan Cesar (2001) melakukan studi di Indonesia untuk menghitung total nilai ekonomi ekosistem Gunung Leuser dengan 2 skenario yang berbeda yaitu (1) skenario konservasi, (2) skenario deforestasi. Total nilai ekonomi ekosistem gunung Leuser dihitung dengan menggunakan Extended CBA dengan jangka waktu analisis selama 30 tahun, dimana manfaat bersih dari kedua skenario tersebut dihitung selama periode tersebut. Hasil studi ini menemukan bahwa selama 10 tahun pertama, skenario deforestasi menghasilkan return yang lebih tinggi, tetapi setelah 10 tahun berikutnya skenario konservasi lebih unggul dibandingkan dengan skenario deforestasi. Total nilai ekonomi untuk kedua skenario tersebut sangat tergantung pada discount rate yang dipilih. Tetapi skenario konservasi mempunyai total nilai ekonomi yang tertinggi pada semua tingkat bunga yang dihitung. Memperhatikan penerapan metode CBA dalam analisis ini yang digunakan untuk membandingkan pilihan alternatif penggunaan kawasan ekosistem hutan dapat dikemukakan bahwa meskipun manfaat bersih konservasi lebih tinggi dibandingkan dengan manfaat deforestasi, namun dalam mencari nilai bersih kedua skenario tersebut, tidak memasukkan opportunity cost dari pilihan alternatif penggunaan ekosistem hutan tersebut baik opportunity cost finansial, lingkungan dan sosial ekonomi. Selain itu jasa ekosistem hutan masih dilihat dalam konteks economi capital bukan sebagai natural capital.

Dalam kaitannya dengan valuasi jasa ekosistem hutan dengan konsep sebagai natural capital, Turner dan Daily (2007) telah melakukan studi dengan menganalisis jasa yang dihasilkan oleh ekosistem sebagai arus capital. Sedangkan metodeyang digunakan untuk melakukan valuasi jasa ekosistem adalah CBA. Hasil studi ini menemukan bahwa nilai jasa ekosistem hutan sebagai natural capital memberikan kontribusi yang sangat signifikan dalam mencapai tingkat kesejahteraan masyarakat. Namun penerapan metode CBA yang digunakan untuk membandingkan pilihan alternatif penggunaan kawasan hutan, tidak memasukkan opportunity cost dari pilihan alternatif penggunaan hutantersebut baik opportunity cost finansial, lingkungan dan sosial ekonomi.

Selain Turner,et.al (2008) juga melakukan studi dengan menerapkan penilaian jasa ekosistem dalam perspektif natural asset. Teknik penilaian menggunakan personal persepsi, dimana setiap individu diminta untuk melakukan valuasi. Hasil studi ini mengemukakan bahwa nilai natural asset bervariasi berdasarkan kepentingan dan kebutuhan individu tersebut terhadap jasa ekosistem dalam kehidupan sosial ekonominya.Meskipun konsepsi yang digunakan dalam melakukan valuasi terhadap jasa ekosistem hutan dalam perspektif natural asset/capital, namun teknik perhitungan dengan menggunakan persepsi individu tidak akurat karena sangat dipengaruhi oleh subjektivitas dan karakteristik individu yang melakukan valuasi. 
Studi berikutnya yang dilakukan oleh Beukering, et.al (2009) mengambil lokasi di Nangroe Aceh Darussalam dengan melakukan valuasi untuk menghitung total nilai ekonomi jasa dan sumberdaya ekosistem hutan di Provinsi NAD. Sama seperti yang dilakukan terhadap ekosistem Gunung Leuser, dalam melakukan valuasi terhadap nilai jasa ekosistem hutan di NAD, ada 2 skenario yang dinilai yaitu (1) skenario Conservasi, dimana dalam skenario ini semua aktivitas yang bersifat ekstratif dihentikan. Jasa ekosistem hutan sepenuhnya dipertahankan dan perekonomian terus menikmati manfaat dari jasa ekosistem hutan di masa mendatang. (2) skenario Deforestasi, dimana dalam skenario ini diasumsikan kegiatan berjalan seperti biasa, dimana tingkat deforestasi sebesar 1.3 persen per tahun. Proporsi tertentu dari lahan dikonversikan menjadi lahan pertanian, yang dampaknya secara perlahan-lahan menyebabkan jasa ekosistem hutan berkurang. Periode analisis dalam studi ini selama 30 tahun. Metode yang digunakan untuk mencari manfaat bersih dari kedua skenario tersebut adalah menggunakan metode CBA. Hasil studi ini memperlihatkan bahwa hingga tahun 2020, skenario deforestasi menghasilkan manfaat sosial ekonomi yang lebih tinggi dari skenario konservasi. Hal ini disebabkan: (a) pendapatan terbesar diperoleh dari kegiatan penebangan kayu dan pengambilan produk hutan non kayu, (b) dampak negatif dari deforestasi masih dalam dimensi yang dapat dikelola. Tetapi setelah tahun 2020, manfaat bersih dari konservasi diatas manfaat yang diperoleh dari kegiatan penebangan kayu. Dengan mencermati hasil studi ini serta penerapan metode CBA dalam analisis ini, dapat dikatakan bahwa penerapan metode CBA untuk membandingkan pilihan alternatif penggunaan kawasan hutan di NAD, tidak memasukkan opportunity cost dari pilihan alternatif penggunaan kawasan hutan tersebut baik opportunity cost finansial, lingkungan dan sosial ekonomi. Selain itu konsep dalam melakukan valuasi terhadap jasa ekosistem hutan masih melihat ekosistem hutan sebagai economic capital dan bukan natural capital.

Sedangkan studi terkini dilakukan oleh Armsworth, et.al (2010) yang melakukan valuasi terhadap jasa ekosistem hutan telah menerapkan konsep nilai asuransi.Sebagaimana ditegaskan oleh Armsworth, et.al (2010) bahwa Nilai asuransi jasa ekosistem terkait erat dengan resilience dan self-organizing capacity, dan fungsi regulasi dari ekosistem hutan. Pandangan ini mempertegas bahwa konsep nilai asuransi dari ekosistem hutan pada dasarnya dikarenakan karakteristik yang melekat pada ekosistem hutan yang memiliki fungsi regulasi. Dengan karakteristik seperti ini maka konsep nilai yang digunakan untuk melakukan valuasi terhadap jasa ekosistem tersebut adalah konsep nilai asuransi. Sehingga total nilai ekonomi jasa ekosistem dibagi menjadi : nilai output (output value) dan nilai asuransi (insurance output).Dalam melakukan valuasi terhadap jasa ekosistem, konsep valuasi yang dilakukan oleh Armsworth et.al (2010) telah membedakan 2 valuasi yaitu output value dan insurance value. Namun dalam implementasinya, valuasi yang dilakukan dengan konsep nilai asuransi hanya untuk manfaat ekosistem hutan yang memiliki fungsi regulasi. Berikut ini konsep pikiran Armsworth, et.al (2010) tentang konsep nilai asuransi dalam valuasi ekosistem hutan yang selanjutnya penulis tuangkan dalam diagram sebagai berikut: 


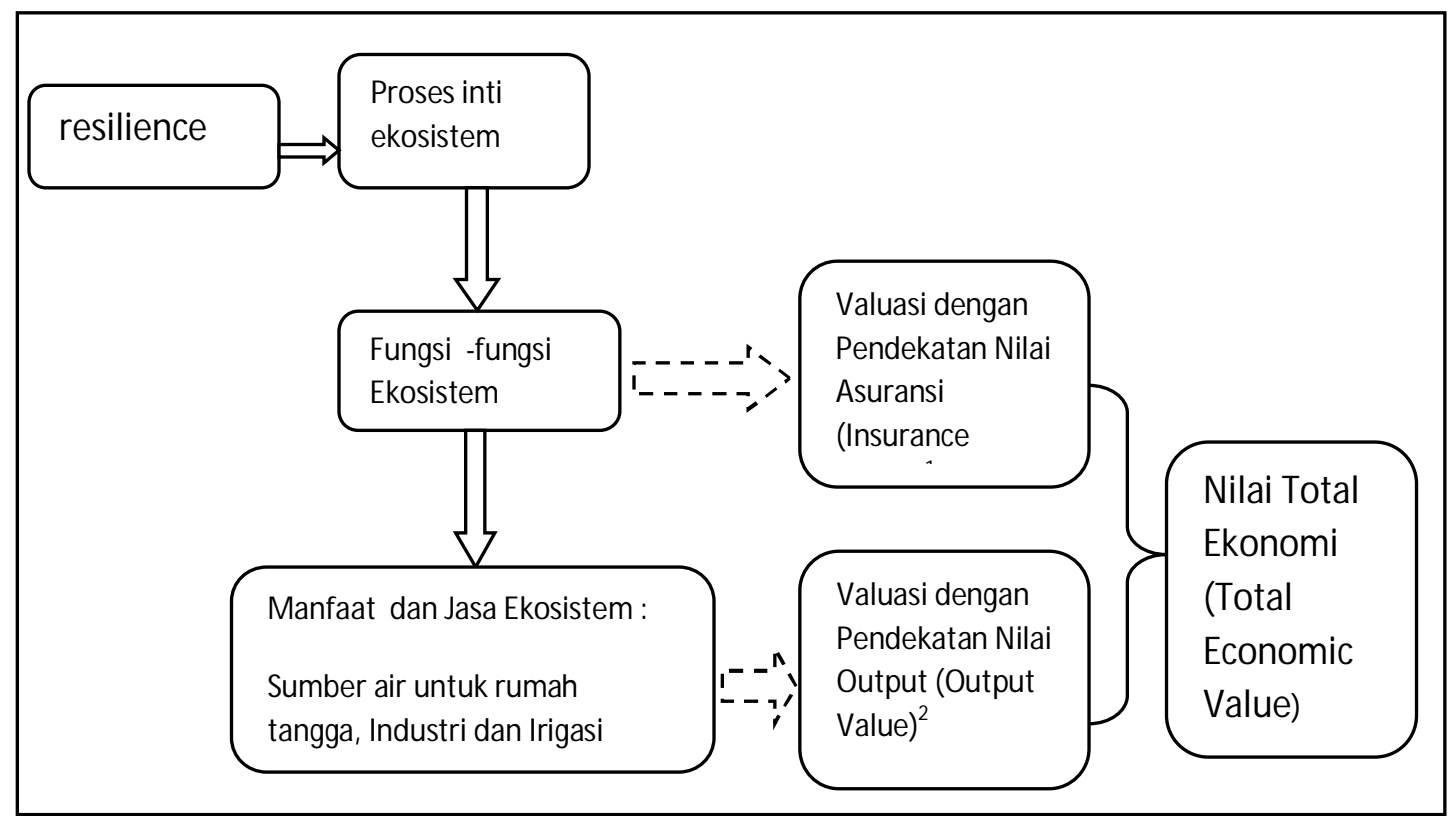

Gambar 2. Konsep Nilai Asuransi yang dikemukakan oleh Armsworth, et.al.

\subsection{Valuasi Ekosistem Hutan Dengan Konsep Nilai Asuransi Dalam Perspektif Natural Asset dan Sosial Asset}

Aspek sosial, budaya dan ekonomimempengaruhi masyarakat suatu daerah ikut berperan dalam menciptakan hubungan yang harmonis dengan hutan maupun lingkungannya. Nilai-nilai sosial dan budaya masyarakat melalui kearifan dan pengetahuan lokal untuk pelestarian lingkungan sudah dikenal sejak dulu. Perwujudkan kearifan lokal masyarakat terhadap lingkungan dapat dialami dalam nilai sosial, norma adat, etika, sistem kepercayaan, pola penataan ruang tradisional, serta peralatan dan teknologi sederhana ramah lingkungan yang diterapkan. Sumber daya sosial yang diwarisi secara turun temurun tersebut, pada berbagai komunitas masyarakat terbukti efektif menjaga kelestarian lingkungan (hutan).

Sistem pengelolaan hutan yang dilakukan oleh masyarakat lokal sebenarnya sudah ada sejak lama dan sebagian mengarah pada kelestarian hutan yang menjamina kelangsung pemanfaatan kehidupan mereka. Hal ini dilakukan melalui proses adaptasi. Kapasitas masyarakat lokal dalam pengelolaan hutan tidak terbatas pada hal-hal teknis semata, tetapi juga menyangkut norma-norma dan etika yang harus dipegang dalam menjamin kelestarian manfaat dalam setiap kegiatan pemanfaatan sumberdayanya (Anonim, 2001). Kondisi diatas sejalan dengan yang dikemukan oleh Nababan (2002) tentang pengelolaan hutan adat oleh masyarakat dimana masyarakat lokal/adat mempunyai motif yang paling kuat untuk melindungi hutan adatnya dibandingkan dengan pihak-pihak berkepentingan lainnya. Motivasi ini didasari oleh keyakinan atas 
hak-hak asal usul yang diwarisi dari leluhur. Selain itu masyarakat adat juga menyadari posisinya sebagai penerima insentif yang paling besar jika hutan adatnya utuh dan terpelihara dengan baik. Sebagai penduduk yang sebagian besar kehidupannya tergantung dengan hutan, hutan yang lestari akan menjamin ketersediaan pangan, ramuan obat-obatan, air bersih, bahan bangunan dan kebutuhan primer lain bagi masyarakat adat. Ketergantungan yang tinggi terhadap hutan tersebut disikapi masyarakat dengan memperlakukan hutan secara bijaksana, tidak berlaku sebaliknya. Norma dan kearifan sosial-budaya yang berasaskan keserasian antara manusia dan lingkungan hidup digunakan untuk memanfaatkan lingkungan hidup bagi kelangsungan kehidupan.

Masyarakat memiliki "kearifan tradisional” (indigenous wisdom). Menurut Keraf (2002) kearifan tradisional merupakan semua bentuk pengetahuan, keyakinan, pemahaman, atau wawasan serta adat kebiasaan atau etika yang menuntun perilaku manusia di dalam komunitas ekologis. Ini berarti hubungan relasional yang dipraktikkan masyarakat adat tidak hanya antar manusia melainkan juga manusia dengan alam atau benda non-manusia. Kearifan tradisional ini bukan rekayasa atau disengaja diciptakan dengan kepentingan tertentu, tetapi ia merupakan seperangkat sistem nilai dan cara pandang yang dipraktikan masyarakat tradisional dalam kehidupannya dan diwariskan secara turun temurun dari generasi moyang leluhurnya.Sehingga dalam masyarakat tradisional,tiap masyarakat hukum adat memiliki tata guna lahan berdasarkan pola pemanfaatan dan produksi subsisten masyarakat desa. Pola mana diatur oleh adat istiadat dan lembaga adat berdasarkan kebutuhan yang disepakati seperti kawasan hutan adat (hutan primer) yang tidak boleh dirusak, kawasan keramat, kawasan hutan untuk ramuan rumah, kawasan pertanian untuk berladang dan kebun, kawasan tembawang baik yang dimiliki secara kolektif atau perseorangan (keluarga). Selain itu pemanfaatan sumber daya hutan berdasarkan pengetahuan asli, kepercayaan adat dan pantangan-pantangan sebagai acuan untuk bertindak terhadap hutan. Mereka tidak menjadikan hutan hanya sebagai objek yang dapat diperlakukan semena-mena, tetapi merupakan bagian hidup mereka, baik dalam arti ekonomi maupun sosial budaya. Adat kepercayaan mereka memiliki arti penting dalam upaya pemeliharaan dan perlindungan hutan (ekologis), sehingga kelestarian hutan tetap terjaga.

Dalam konteks valuasi ekonomi, nilai-nilai budaya yang dimiliki masyarakat memberikan kontribusi dalam menentukan nilai dari suatu jasa ekosistem hutan. Apabila dicermati, nilai warisan dan nilai eksistensi yang merupakan bagian dari nilai non penggunaan, pada dasarnya merupakan pencerminan dari bentuk nilai yang berasal dari kearifan lokal yang dimiliki masyarakat dalam mempertahankan keberlanjutan ekosistem hutan. Nilai warisan merupakan nilai ekonomi jasa ekosistem hutan yang diperoleh dari manfaat pelestarian ekosistem hutan untuk kepentingan generasi mendatang. Nilai ini muncul karena adanya nilai sebuah sistem tradisional masyarakat yang terkait dengan ekosistem, habitat dan keanekaragaman hayati. Sedangkan nilai eksistensi adalah nilai ekonomi jasa ekosistem hutan yang diperoleh dari persepsi masyarakat (masyarakat tradisional) untuk tetap mempertahankan keberadaan suatu 
sumberdaya (ekosistem hutan), terlepas dari sumberdaya (ekosistem hutan) tersebut dimanfaatkan atau tidak. Dengan pemahaman nilai warisan dan nilai eksistensi ekosistem hutan tersebut, secara implisit nilai yang terkandung dari kedua nilai tersebut adalah menganut nilai-nilai keberlanjutan yang secara konsepsinya merupakan konsep dari nilai asuransi.

Konsep yang melihat ekosistem hutan sebagai natural asset adalah konsep yang dikemukakan oleh beberapa ahli termasuk Amsworth, et.al (2010). Menurut Amsworth et.al (2010), dengan karakteristik seperti ini maka konsep nilai yang digunakan untuk melakukan valuasi terhadap jasa ekosistem tersebut adalah konsep nilai asuransi. Pandangan ini mempertegas bahwa konsep nilai asuransi dari ekosistem hutan pada dasarnya dikarenakan karakteristik yang melekat pada ekosistem hutan yang memiliki fungsi regulasi. Cara pandang seperti ini memarginalkan fungsi ekosistem hutan lainnya, seperti fungsi sosial ekonomi. Padahal konsep nilai asuransi dari ekosistem hutan bukan hanya terjadi karena dilihat dari perspektif sebagai natural capital, tetapi peran dari nilainilai sosial dalam menjaga keberlanjutan ekosistem hutan sangat penting yang tercermin dengan adanya nilai warisan dan nilai eksistensi. Oleh karena itu dalam penelitian ini, konsep nilai asuransi dari ekosistem hutan terjadi karena ekosistem hutan berfungsi sebagai natural asset/natural capital dan social asset/social capital. Inilah perbedaan konseptual dari konsep nilai asuransi yang dikemukakan oleh Amswoth et.al (2010) dengan konsep nilai asuransi yang memasukkan aspek nilai warisan dan nilai eksistensi sebagai suatu refleksi dari nilai-nilai kearifan lokal yang ada di masyakarat.

Sementara itu secara substansial terdapat perbedaan dalam cakupan konsep valuasi ekosistem hutan, dalam hal ini Paul Amsworth et.al (2010) melakukan valuasi dengan konsep nilai asuransi terhadap jasa ekosistem hutan hanya pada fungsi regulasinya (manfaat lingkungan), sedangkan dalam konsep tulisan valuasi yang dilakukan dengan menggunakan konsep nilai asuransi sudah memasukkan aspek sosioekologis bukan hanya memfokuskan pada fungsi regulasi ekosistem hutan (manfaat lingkungan), tetapi juga memfokuskan pada fungsi ekosistem hutan secara keseluruhan termasuk fungsi sosial ekonomi yang terkait dengan kearifan lokal masyarakat dalam pengelolaan hutan. 


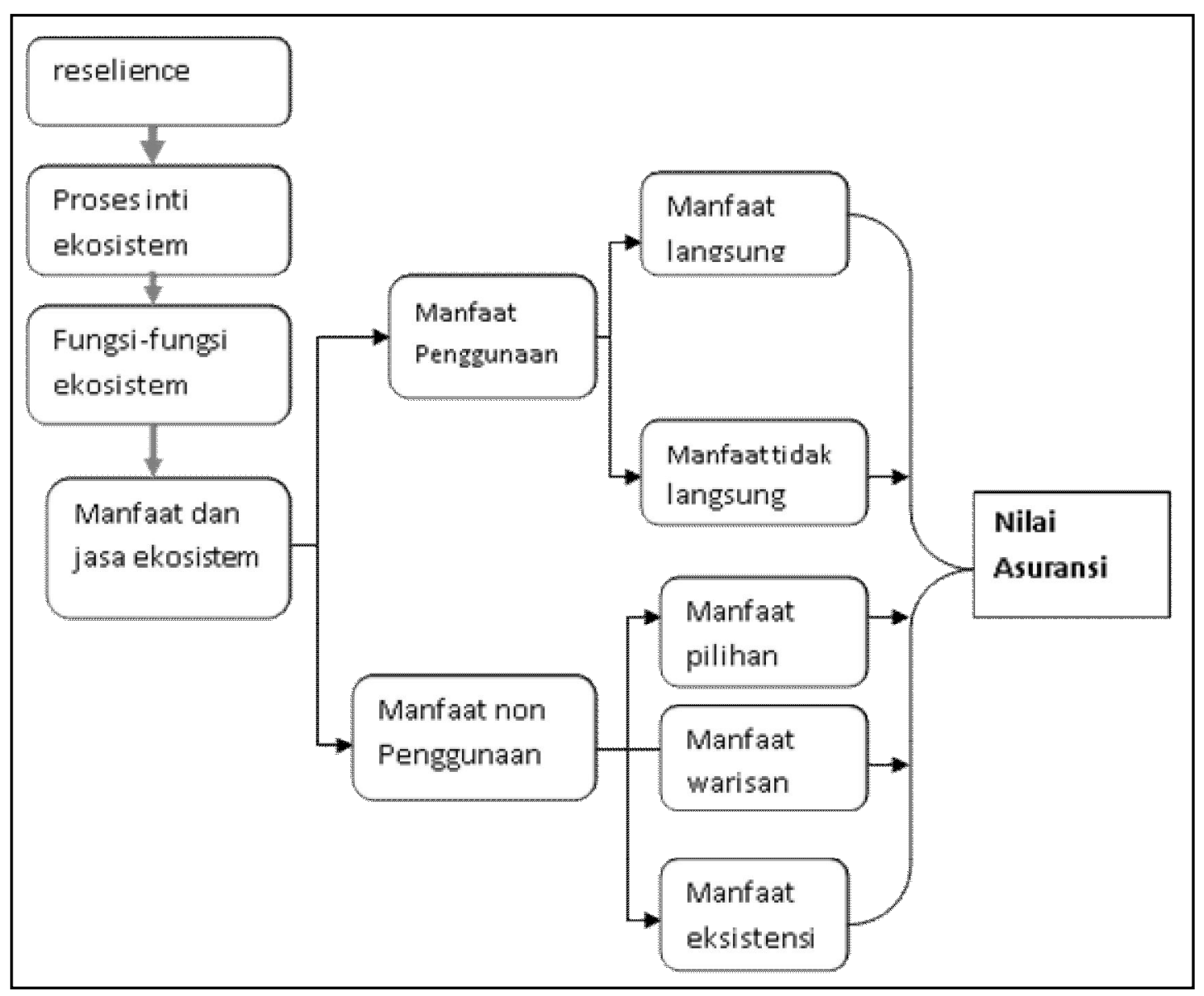

Gambar 3. Konsep Nilai Asuransi dalam perspektif natural asset dan sosial asset

Konsep yang ditawarkan dalam melakukan valuasi adalah dengan melihat jasa ekosistem hutan sebagai natural asset dan social assetdengan melakukan valuasi menggunakan konsep nilai asuransi. Prinsip-prinsip yang digunakan dalam melakukan valuasi terhadap jasa ekosistem hutan dalam konsep valuasi ini diantaranya adalah (1) Ekosistem hutan dilihat dari perspektif natural assetdan social asset (2) Ekosistem hutan sebagai bagian dari life supporting system mempunyai sifat keberlanjutan dan dinamis, tidak mengalami penurunan carriyng capacity selama tidak ada intevensi yang dilakukan oleh manusia atau tidak ada kejadian dan peristiwa yang luar biasa seperti bencana gempa dan banjir besar. Selain itu dengan karakteristik sustainable tersebut, maka tidak ada konsep depresiasi dalam nilai ekosistem hutan. Bahkan sebaliknya nilai ekosistem hutan akan semakin meningkat di masa mendatang, (3) konsep yang digunakan untuk melakukan valuasi terhadap jasa ekonomi sistem hutan adalah konsep nilai asuransi dalam perspektif natural asset dan social asset. 


\subsection{Kerangka Konsep}

Penerapan konsep penilaian secara komprehensif jasa lingkungan yang disediakan oleh hutan dan menginternalkan biaya sosial dan lingkungan ke dalam kelayakan kegiatan perkebunan kelapa sawit, maka diduga kuat bahwa nilai jasa lingkungan yang disediakan oleh hutan lebih besar dibandingkan dengan rente ekonomi kegiatan perkebunan kelapa sawit. Selain itu, dengan penerapan konsep penilaian secara komprehensif jasa lingkungan yang disediakan oleh hutan dengan konsep nilai asuransi maka hal ini tidak hanya memberikan solusi bagi pencegahan deforestasi dan degradasi sehingga mampu untuk mengurangi pemanasan global, tetapi juga dapat memberikan manfaat bagi pengelolaan hutan secara berkelanjutan baik dari aspek lingkungan, ekonomi dan sosial. Usulan rerangka konsep untuk menganalisis kelayakan perkebunan kelapa sawit dan ekosistem hutan dapat dilihat pada Gambar 4.

\section{Model Penentuan Optimasi Areal Perkebunan Kelapa Sawit pada Kawasan Ekosistem Hutan}

Model penentuan optimasi luas areal perkebunan kelapa sawit diperoleh dari beberapa variabel dan persamaan. Hasil perhitungan beberapa variabel tersebut adalah:

Menghitung Persamaan Nilai Untuk Perkebunan Kelapa Sawit

- $\mathrm{MF}_{\mathrm{PKS}}=\left(\mathrm{X} 1_{\mathrm{PKS}} \cdot \mathrm{X} 2_{\mathrm{PKS}}\right)+\left(\mathrm{X} 3_{\mathrm{PKS}}\right)$

- $\mathrm{ML}_{\mathrm{PKS}}=\left(\mathrm{X} 4_{\mathrm{PKS}}+\mathrm{X} 5_{\mathrm{PKS}}+\mathrm{X} 6_{\mathrm{PK}}+\mathrm{X} 7_{\mathrm{PKS}}+\mathrm{X} 8_{\mathrm{PKS}}\right)$.

- $\mathrm{MSE}_{\mathrm{PKS}}=\left(\mathrm{X} 9_{\mathrm{PKS}}+\mathrm{X} 10_{\mathrm{PKS}}+\mathrm{X} 11_{\mathrm{PKS}}\right)$

- $\mathrm{M}_{\mathrm{TPKS}}=\left(\mathrm{M}_{\mathrm{FPKS}}+\mathrm{M}_{\mathrm{LPKS}}+\mathrm{MS}_{\mathrm{EPKS}}\right)$

- $\mathrm{BF}_{\mathrm{PKS}}=\left(\mathrm{X} 11_{\mathrm{PKS}}+\mathrm{X} 12_{\mathrm{PKS}}+\mathrm{X} 13_{\mathrm{PKS}}+\mathrm{X} 14_{\mathrm{PKS}}+\mathrm{X} 15_{\mathrm{PKS}}+\mathrm{X} 16_{\mathrm{PKS}} \mathrm{X}+17_{\mathrm{PKS}}+\mathrm{X} 18_{\mathrm{PKS}}\right)$

- $\mathrm{BL}_{\mathrm{PKS}}=\left(\mathrm{X} 1_{\mathrm{EH}}+\mathrm{X} 2_{\mathrm{EH}}+\mathrm{X} 3_{\mathrm{EH}}+\mathrm{X} 4_{\mathrm{EH}}+\mathrm{X} 5_{\mathrm{EH}}+\mathrm{X} 6_{\mathrm{EH}}+\mathrm{X} 7_{\mathrm{EH}}+\mathrm{X} 8_{\mathrm{EH}}+\mathrm{X} 9_{\mathrm{EH}}+\mathrm{X} 10_{\mathrm{EH}}+\mathrm{X} 11_{\mathrm{EH}}+\mathrm{X} 12_{\mathrm{EH}}\right)$

- $\mathrm{BS}_{\mathrm{EPKS}}=\left(\mathrm{X} 1_{3 \mathrm{EH}}+\mathrm{X} 1_{4 \mathrm{EH}}\right)$

- $\mathrm{BT}_{\mathrm{PKS}}=\left(\mathrm{BF}_{\mathrm{PKS}}+\mathrm{BL}_{\mathrm{PKS}}+\mathrm{BSE}_{\mathrm{PKS}}\right)$.

- $\mathrm{YB}_{\mathrm{PKS}}=\left(\mathrm{MT}_{\mathrm{PKS}}-\mathrm{BT}_{\mathrm{PKS}}\right)$

Menghitung Persamaan Untuk Ekosistem Hutan

- $\mathrm{MF}_{\mathrm{EH}}=\left(\mathrm{X} 1_{\mathrm{EH}}+\mathrm{X} 2_{\mathrm{EH}}\right)$

- $\mathrm{M}_{\mathrm{LEH}}=\left(\mathrm{X}_{3 \mathrm{EH}}+\mathrm{X}_{4 \mathrm{EH}}+\mathrm{X}_{5 \mathrm{EH}}+\mathrm{X}_{6 \mathrm{EH}}+\mathrm{X}_{7 \mathrm{EH}}+\mathrm{X}_{8 \mathrm{EH}}+\mathrm{X}_{9 \mathrm{EH}}+\mathrm{X} 1_{0 \mathrm{EH}}+\mathrm{X} 1_{1 \mathrm{EH}}+\mathrm{X} 1_{2 \mathrm{EH}}\right)$

- $\mathrm{MSE}_{\mathrm{EH}}=\left(\mathrm{X} 13_{\mathrm{EH}}+\mathrm{X} 14_{\mathrm{EH}}\right)$

- $\mathrm{MT}_{\mathrm{EH}}=\left(\mathrm{MF}_{\mathrm{EH}}+\mathrm{ML}_{\mathrm{EH}}+\mathrm{MSE}_{\mathrm{EH}}\right)$.

- $\mathrm{BF}_{\mathrm{EH}}=\left(\mathrm{X} 1_{\mathrm{PKS}} \cdot \mathrm{X} 2_{\mathrm{PKS}},\right)$

- $\mathrm{BL}_{\mathrm{EH}}=\left(\mathrm{X} 4_{\mathrm{PKS}}+\mathrm{X} 5_{\mathrm{PKS}}+\mathrm{X} 6_{\mathrm{EH}}+\mathrm{X} 7_{\mathrm{PKS}}+\mathrm{X} 8_{\mathrm{PKS}}\right)$

- $\mathrm{BS}_{\mathrm{EEH}}=\left(\mathrm{X}_{9 \mathrm{PKS}}+\mathrm{X} 1_{0 \mathrm{PKS}}+\mathrm{X} 1_{1 \mathrm{PKS}}\right)$

- $\mathrm{BT}_{\mathrm{EH}}=\mathrm{f}\left(\mathrm{BF}_{\mathrm{EH}}+\mathrm{BL}_{\mathrm{EH}}+\mathrm{BSE}_{\mathrm{EH}}\right)$

- $\mathrm{YB}_{\mathrm{EH}}=\left(\mathrm{MT}_{\mathrm{EH}}-\mathrm{BT}_{\mathrm{EH}}\right)$ 


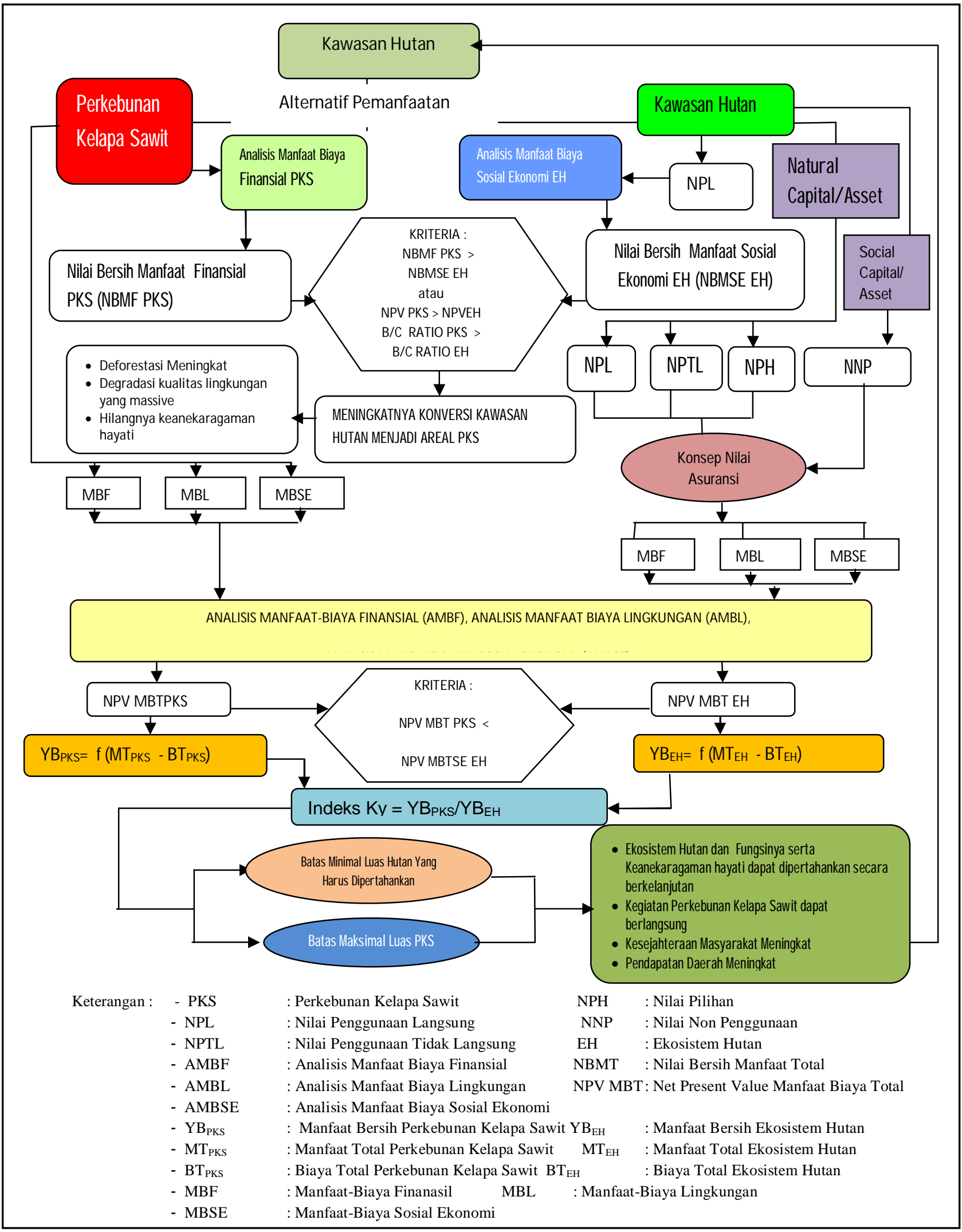

Gambar 4. Kerangka Konsep Analisis Kelayakan Perkebunan Kelapa Sawit dan Ekosistem

\section{Hutan}


Berdasarkan model penentuan optimasi areal perkebunan kelapa sawit pada kawasan hutan, maka secara regresi Indeks Ky adalah:

$$
\begin{aligned}
& \mathrm{t}=\mathrm{n} \\
& \Sigma \mathrm{YB}_{\mathrm{PKS}} \\
& \mathrm{t}=0 \ldots . \mathrm{n}, \mathrm{n}=25 \text { tahun } \\
& \text { Indek Ky (IKy) = --- } \\
& \Sigma \mathrm{YB}_{\mathrm{EH}} \\
& \mathrm{t}=0 \ldots \ldots \ldots . . \mathrm{n}, \mathrm{n}=25 \text { tahun }
\end{aligned}
$$

Indeks ini disebut dengan Social Economy dan Environment Compromise Indeks (SEECI). Dengan diketahuinya angka IKy, maka dapat diformulasikan rumus untuk mencari kelayakan luasan perkebunan kelapa sawit pada lahan hutan tertentu dengan persamaan sebagai berikut:

$$
\begin{gathered}
\mathrm{HT} \\
\mathrm{K}_{\mathrm{ys}}= \\
\mathbf{1}
\end{gathered}
$$

dimana :

$$
\begin{array}{ll}
\mathrm{K}_{\mathrm{ys}} & =\text { Kelayakan luas perkebunan kelapa sawit } \\
\mathrm{HT} & =\text { Luas Hutan yang tersedia } \\
\text { IKy } & \text { = Indeks Ky }
\end{array}
$$

Bentuk lain dari rumus di atas dapat digunakan untuk menentukan kelayakan luas kawasan hutan yang harus dipertahankan, apabila ada rencana untuk membuka areal perkebunan kelapa sawit dengan luasan tertentu pada kawasan hutan. Rumus untuk menentukan kelayakan luas kawasan hutan yang harus dipertahankan adalah sebagai berikut:

$$
\mathrm{K}_{\mathrm{yh}}=-\mathrm{IKY} . \mathrm{Kys}
$$

dimana :

$\mathrm{K}_{\mathrm{yh}} \quad=$ Kelayakan luas hutan yang harus dipertahankan

$\mathrm{K}_{\mathrm{ys}} \quad=$ Luas Perkebunan Kelapa Sawit yang direncanakan

IKY = Indeks KY 


\section{Model Umum}

Dengan mengikuti 5 (lima ) prosedur pokok dalam melakukan valuasi ekonomi terhadap ekosistem hutan dan perkebunan kelapa sawit yang disajikan berikut ini, maka akan ditemukan model umum penentuan kelayakan luas perkebunan kelapa sawit pada kawasan ekosistem hutan.

a. Penerapan valuasi terhadap manfaat ekosistem hutan dan perkebunan kelapa sawit dengan pendekatan HHCA (head to head comperative analyisis) harus mendefinisikan ekosistem hutan sebagai natural asset/natural capital dan social asset/social capital serta menerapkan konsep nilai asuransi (insurance value) terhadap manfaat dari fungsi ekosistem hutan.

b. Melakukan internalisasi dampak eksternalitas kedalam 3 aspek analisis yaitu analisis manfaat-biaya finansial, analisis manfaat biaya lingkungan dan analisis manfaat biaya sosial ekonomi untuk masing-masing kegiatan perkebunan kelapa sawit dan ekosistem hutan.

c. Seluruh komponen opportunity cost harus diperhitungkan dalam menganalisis manfaat bersih perkebunan kelapa sawit dan ekosistem hutan.

d. Konsep depresiasi tidak berlaku dalam ekosistem hutan, maka dalam menghitung nilai bersih ekosistem hutan haruslah dilakukan dengan menggunakan konsep future value.

e. Dalam konteks arus uang, arus penerimaan untuk kegiatan perkebunan kelapa sawit diperlakukan sebagai dana simpanan, sedangkan arus pengeluaran diperlakukan sebagai dana pinjaman. Sebaliknya untuk ekosistem hutan, baik arus manfaat maupun arus biaya (atau opportunity cost) tetap menerapkan faktor future value.

\section{Kesimpulan}

Laju alih fungsi kawasan hutan yang sangat massive di Indonesia untuk dijadikan lahan perkebunan kelapa sawit dalam beberapa dekade belakangan ini, salah satunya dipicu oleh pendekatan valuasi terhadap ekosistem hutan yang lebih menekankan konsep present value dan menganggap fungsi ekosistem hutan bersifat statis. Sehingga dengan konsep ini, nilai ekonomi ekosistem hutan menjadi lebih kecil dibandingkan dengan nilai ekonomi perkebunan kelapa sawit.

Penerapan konsep nilai asuransi dalam melakukan valuasi terhadap ekosistem hutan, menekankan pada konsep future value dan menganggap fungsi ekosistem hutan bersifat arus yang dinamis dan berkembang. Sehingga dengan konsep ini, nilai ekonomi ekosistem hutan menjadi lebih besar dibandingkan dengan nilai ekonomi perkebunan kelapa sawit. 
Memperbandingkan hasil valuasi ekosistem hutan dengan penerapan konsep nilai asuransi dengan hasil valuasi perkebunan kelapa sawit akan mendapatkan indeks kelayakan luas perkebunan kelapa sawit dalam suatu kawasan hutan. Indeks kelayakan luas perkebunan kelapa sawit dalam suatu kawasan hutan digunakan untuk menentukan luas maksimal kawasan hutan yang paling layak untuk dialihfungsikan menjadi lahan perkebunan kelapa sawit, yang dapat memberikan keseimbangan baik dari aspek lingkungan, ekonomi dan sosial.

\section{DAFTAR PUSTAKA}

Alcorn, J. B. (1989). An Economic Analysis of Huastec Mayan Forest Management. InBrowder, J.O. (Ed.),Fragile Lands of Latin America: Strategies for SustainableDevelopment(pp. 182-206). Westview Press: Boulder.

Van Beukering, P. J. H \& Cesar, H. S. J. (2001). Economic valuation of the Leuser Ecosystem on Sumatra, Indonesia: A stakeholder perspective. Amsterdam : The Netherlands.

Brown, K. and Pearce, D. W. (Eds.). (1994). The Causes of Deforestation: The Economic and Statistical Analysis of Factors Giving Rise to the Loss of Tropical Forests. UCL Press London, 217-225.

Barbier, E. B., Burgess, J. C. and Folke, C. (1994). Paradise Lost?. The Ecological Economicsof Biodiversity. London : Earthscan Publications.

Brown, N. (1998). Degeneration versus Regeneration - Logging in Tropical Rainforests. In Goldsmith, F.B. (Ed.),Tropical Rain forest: a Wider Perspective(pp.416). London : Chapman and Hall.

Ball, J. B. (2001). Global Forest Resources; History and Dynamics. In Evans, J. (Ed.), The Forests Handbook Vol. I. (pp.418). Oxford: Blackwell Science.

Barde, J. (1996). Environmental Taxation: Experience in OECD Countries. In T.O'Riordan (Ed.), Ecotaxation (pp.223-245). London: Earthscan Publications.

Beltratti, A., Chichilnisky, G., \& Heal, G. (1993). Preservation, Uncertain Future Preferences and Irreversibility.Working Paper,(59-93). Milano: Fondazione ENI Enrico Mattei.

Boehmer-Christiansen, S. (1994). The Precautionary Principle in Germany - Enabling Government. In Timothy O'Riordan and James Cameron (Eds.), Interpreting the Precautionary Principle (pp. 31-60). London: Earthscan Publications. 
Bovenberg, A. L., \& Goulder, L. H . (1995). Costs of Environmentally Motivated Taxes in the Presence of Other Taxes: General Equilibrium Analyses.Working Paper No. 5117. Cambridge (Mass.): National Bureau of Economic Research.

Brown, K., Pearce, D. W., Perrings, C. and Swanson, T. (1994). Economics and the Conservation of Global Biological Diversity. Working Paper No. 2. Washington D.C.: Global Enironment Facility.

Callan, S. J. \& Thomas, J. M. (1996).Environmental Economics and Management; Theory, Policy, and Applications. USA : Irwin.

Carraro, C., Galeotti, M. and Gallo, M. (1996). Environmental Taxation and Unemployment: Some Evidence on the 'Double Dividend Hypothesis' in Europe. Journal of Public Economics, 62,141-181.

Castle, E. N. and Berrens, R. P. (1993). Endangered Species, Economic Analysis, and the Safe Minimum Standard. Northwest Environmental Journal, 9, 108-130

Clark, C. W. (1995). Scale and the Feedback Mechanism in Market Economics. In Timothy Swanson (Ed.),The Economics and Ecology of Biodiversity Decline - The Forces driving Global Change (pp. 143-148). Cambridge: Cambridge University Press.

Costanza, R. (1994). Three General Policies to Achieve Sustainability. In A. Jansson, M. Hammer, C. Folke and R. Costanza (Eds.),Investing in Natural Capital: The Ecological Economics Approach to Sustainability (pp. 392-407). Washington D.C.: Island Press.

Davies, J. \& Richards, M. (1999).The Use of Economics to Assess Stakeholder Incentives in Participatory Forest Management: A Review. European Union Tropical Forestry Paper 5. London: Overseas Development Institute.

Diamond, P. A \& J. A. Hausman. (1994). Contingent valuation: Is some number better than no number? Journal of Economic Perspectives Fall 94, 8(4), 45-65.

Fauzi, A, dan Anna S. (2005). Pemodelan Sumberdaya Perikanan dan Lautan Untuk Analisis Kebijakan. Jakarta: Gramedia Pustaka Utama.

Gatzweiler, F. W. (2003). The Changing Nature of Economic Value. Indigenous Forest Garden Values in Kalimantan, Indonesia. In V. Beckmann and K. Hagedorn (Eds.),Institutional Change in Agriculture and Natural Resources, Vol.16.

Goldman, M.(1977). The Convergences of Environmental Disruption. In R. Dorfman and N. Dorfman (Eds.), Economics Of Environment. NY: Norton. 
Glasbergen, Peter (ed.) .(1995). Managing Environmental Disputes: Network Management as anAlternative. Dordrecht, The Netherlands: Kluwer Academic Publishers.

Gregersen, H., Arnold, J., Lundgran, A., Contreras-Hermosilla, A. (1995). Valuing forests: context, issues and guidelines. FAO Forestry Paper 127. Rome.

Grimble, R. \& Wellard, K. (1997). Stakeholder Methodologies in Natural Resource Management: a Review of Principles, Contexts, Experiences and Opportunities. Agricultural Systems, 55 (2), 173-193.

Groot, R. S. De. (1992). Functions of nature; evaluation of nature in environmental planning, management and decision-making. The Netherlands: WoltersNoordhoff, Groningen.

Hadker, N., Sharma, S., David, A. \& Muraleedharan, T. R. (1997). Willingness-to-pay for Borivli National Park: evidence from a Contingent Valuation. Ecological Economics, 21(1977), 105-122.

Hamilton, S. \& Anderson. (1991).Voice Unheard and Unheeded in Biodiversity, Social and Ecological Perspective. Penang: Juta Print.

Hein, L. G. and H.A.M. de Kruijf. (1997).Monetary and Non-monetary Valuation of Biodiversity for the Countries of the Sustainable Development Agreements: Functions, Values and Techniques. NW\&S Report No. 97002. The Netherlands: Department of Science, Technology and Society, Utrecht University.

Hufschmidt, M., et.al. (1992). Lingkungan, Sistem Alami dan Pembangunan: Pedoman Penilaian Ekonomis. Terjemahan, Cetakan Kedua.Yogyakarta : Gajah Mada University Press.

Corzine, J. S. \& Jackson, L. P. (2007, April).Valuing New Jersey's Natural Capital:An Assessment of the Economic Value of the State's Natural Resources. State of New Jersey : New Jersey Department of Environmental Protection.

Junaidi. (2005).Analisis Manfaat Biaya Penerapan Pertanian Pada Lahan Konversi. Studi Kasus: Perkebunan Kelapa Sawit dan Perkebunan Karet di Kabupaten Kampar Provinsi Riau (Tesis). Jakarta : Program Studi Ilmu Lingkungan Program Pascasarjana Universitas Indonesia.

Kahn, J. R. (1996).Trade-off based indicators of environmental quality: an environmental analogue of GDP. Department of Economics, University of Tennessee, Knoxville, TN. 
Kramer, R. A., Sharma, N. \& Munasinghe, M. (1995).Valuing Tropical Forests. Methodology and Case Study of Madagascar. World Bank Environment Paper Number 13. Washington, D.C., USA: World Bank.

Meijerink, G. W. (2001).Functions of Nature. Course Handout of the International Course on Decision-making in natural resources management; Economics for the Environment. International Agricultural Centre, Wageningen.

Munasinghe, M. (1992).Environmental Economics and Valuation in Development Decision making, Environment Working Paper No. 51. Washington: Environment Department, Sector Policy and Research Staff, The World Bank.

Neumayer, E. (2000). Preserving Natural Capital in a World of Uncertainty and Scarce Financial Resources.International Journal of Sustainable Development and World Ecology, 5 (1), 27-42.

Pearce, D. W, Vanclay, J. Futz, F. (2001). Sustainable Forestry in the Tropics: Panacea or Folly?. Forest Ecology and Management, 5839, 1-19.

Pearce,D. W, Vanclay, J. Futz, F. (2001). Sustainable Forest Future ?. In Pearce, D.W and Pearce C (Eds.), Valuing The Environment in The Developing Countries: Case Studies. Cheltenham, UK : Edward Elgar.

Palo, M. (1999). No end to deforestation?. InPalo, M. and Uusivuori, J. (Eds.),World forests, society and environment (pp. 65-77). Netherlands: Kluwer Academic Publishers.

Porto, J. G. (2002). Contemporary Conflict Analysis in Perspective (Chapter One). In Lind, J. et al., Scarcity and Surveit: The Ecology of Africa's Conflicts. Kenya : ACTS.

Paul A., et.al. (2010).The Economics Of Valuing Ecosystem Services And Biodiversity. The Economics of Ecosystems and Biodiversity: The Ecological and Economic Foundations. TEEB Central Office UNEP, Bonn.

Randall, A., et.al. (1994, August 1). Bidding Game for of Aesthetic environmental Improvement. Journal of Environmental Economics and Management, 13249.

Verweij, P. (2002). Understanding and capturing the multiple values of tropical forests. In P. Verweij (Ed.). Proceedings of the international seminar on valuation and innovative financing mechanisms in support of conservation and sustainable management of tropical forests (pp.140). Wageningen, The Netherlands: Tropenbos International. 